\title{
Mucosal biotransformation rates in the small intestine of children
}

\author{
M-R STÅHLBERG, E HIETANEN, AND M MÄKI \\ From the Departments of Paediatrics and Physiology, University of Turku, and Department of Paediatrics, \\ University of Tampere, Finland
}

\begin{abstract}
SUMMARY Biotransformation of ingested xenobiotics is known to take place in the gastrointestinal mucosa of laboratory animals and adult humans as well as in the liver. We studied the activities of aryl hydrocarbon hydroxylase, epoxide hydrolase, and glutathione peroxidase in $\mathbf{2 4 2}$ peroral small intestinal biopsy samples of children aged eight months to 18 years: 201 with normal histology, 21 with partial villous atrophy, and 20 with severe villous atrophy. All these enzymes were detectable even in the youngest children. The aryl hydrocarbon hydroxylase activity was age dependent, while the other measured enzyme activities were not related to the age of the patients. The aryl hydrocarbon hydroxylase activity was not related to the mucosal histology, but the epoxide hydrolase and glutathione peroxidase activities were diminished in samples with severe villous atrophy as compared with normal mucosa. This suggests that small intestinal mucosa with villous atrophy may produce oxidated, reactive metabolites, but further metabolism into detoxication products is decreased. This may expose persons with mucosal atrophy to possible harmful effects of environmental xenobiotics entering the body even at low doses.
\end{abstract}

Human exposure to xenobiotics (xenos=foreign; bios $=$ life ;enobiotics $=$ foreign compounds), present in nature or produced by man, is one of the major present concerns. The oral exposure is of great importance as together with nutrients man ingests various additives, contaminants, and traces of other xenobiotics. Biotransformation of these chemicals into water-soluble metabolites for excretion takes place in the liver but also extrahepatic organs are capable to metabolise xenobiotics. ' The extrahepatic biotransformation is particularly important at ports of entry where man is exposed to small doses of xenobiotics. ${ }^{2}$ Ingested xenobiotics are absorbed into gastrointestinal mucosa mainly by passive diffusion. In enterocytes, xenobiotics are oxidised and subsequently conjugated to water soluble derivatives which are transported for renal or biliary excretion or excreted back into the intestinal lumen. ${ }^{+\infty}$

Aryl hydrocarbon hydroxylase is a microsomal

Address for correspondence: Dr M-R Ståhlberg, Department of Paediatrics, Turku University Hospital, SF-20520 Turku. Finland.

Received for publication 3 March 1988. cytochrome P-450 dependent monooxygenase catalysing - for example, the conversion of polycyclic hydrocarbons to more polar, oxygenated compounds. ${ }^{7}$ Aryl hydrocarbon hydroxylase is detectable and inducible in a number of extrahepatic tissues. ${ }^{8}$ Intestinal aryl hydrocarbon hydroxylase activity is greatest in proximal small bowel decreasing along the intestine. ${ }^{9}$ Epoxides, highly toxic metabolites initially formed from polycyclic hydrocarbons by monooxygenases like aryl hydrocarbon hydroxylase, can cause mutagenesis and carcinogenesis by binding covalently to intracellular macromolecules - for example, DNA. Epoxides may be detoxified by epoxide hydrolase catalysing the conjugation of epoxides with water yielding dihydrodiols. Within the enterocyte, the highly reactive oxygenated products may also be transported from the endoplasmic reticulum to cytosol where they may be conjugated with glutathione catalysed by glutathione-Stransferases, ${ }^{11}$ or reduced by glutathione peroxidase which under physiological conditions protects tissues from oxidative damage."

The intestinal activities of 7-ethoxycoumarin $\mathrm{O}$ - 
deethylase and NADPH-cytochrome c reductase have been evaluated in adult humans. ${ }^{12}$ The present knowledge about intestinal biotransformation is in other respects derived from animal studies. As, particularly, nothing is known about the development of mucosal biotransformation during childhood we decided to study intestinal activities of aryl hydrocarbon hydroxylase, epoxide hydrolase, and glutathione peroxidase in children. The specific purpose of the study was to find out the existing enzyme concentrations in small intestinal mucosa during childhood and to see whether mucosal damage, through different proportions of oxidising $v$ conjugating enzymes, might expose children to harmful metabolites of xenobiotics.

\section{Methods}

\section{PATIENTS}

A total of 242 children, equal numbers of both sexes, were investigated because of failure to thrive, loose stools or chronic diarrhoea, abdominal pains, or raised concentrations of serum antigliadin or antireticulin antibodies. The ages of the children varied from 8 months to 18 years. After exclusion of disease 142 children were found to be healthy; the symptoms had disappeared or they were considered constitutional or functional. Among the remaining patients, in addition to children with coeliac disease, there were children with insulin dependent diabetes mellitus, juvenile rheumatoid arthritis, cow's milk protein intolerance, and inflammatory bowel disease. Peroral intestinal biopsies were taken as a part of the patients' clinical work up and the enzyme measurements brought no additional discomfort to the children. The study was approved by the ethical committee of the Department of Paediatrics, Turku University Hospital.

\section{BIOPSY SPECIMEN}

After fasting (infants for six hours, older children over night), peroral small intestinal biopsies were taken between nine and $11 \mathrm{am}$ at the ligament of Treitz with rapid technique using either a two port paediatric Crosby-Kugler capsule or a paediatric Watson capsule. When a Crosby-Kugler capsule was used one of the two specimens was taken for histology and the other for enzymatic determinations. The single specimen obtained with a Watson capsule was divided in two parts: one for histology, the other for enzyme measurements. Biopsy specimens for enzyme studies were immersed in normal saline, immediately cooled, and stored at $-80^{\circ} \mathrm{C}$.

HISTOLOGY

The fresh biopsy specimens were inspected with a stereomicroscope followed by the preparation of paraffin sections and standard staining with haematoxylin and eosin. The histology was evaluated by pathology staff and, in addition, all pathological and many normal findings were confirmed by Professor JK Visakorpi. The villous structure was normal in 201 biopsies. Partial villous atrophy with stunted and broadened villi was found in 21 children and 20 biopsies showed severe villous atrophy with hyperplastic crypts. No submucosal layers were included in biopsies.

\section{ENZYME ASSAYS}

All assays were carried out independently of the clinical findings. Because of the small sample sizes, optimal assay conditions were predetermined using rat small intestine. After thawing, the biopsy specimens were weighted and homogenised in $1 \mathrm{ml}(0.15 \mathrm{M}$ potassium chloride. Protein concentrations were measured according to Lowry..$^{13}$ Alkaline phosphatase activities were measured spectrophotometrically ${ }^{14}$ using $50 \mu \mathrm{l}$ intestinal homogenate; the linearity and saturation kinetics are described before..$^{14}$

The aryl hydrocarbon hydroxylase activity was measured with the radiochemical method of DePierre et al: ${ }^{15} 25 \mu \mathrm{l}$ intestinal homogenate, $100 \mu \mathrm{l}$ NADPH regenerating system, $10 \mu \mathrm{l}$ tritiated benzo(a)pyrene, and water added to the final volume of $250 \mu \mathrm{l}$ were incubated for 45 minutes; the reaction was stopped with $250 \mu \mathrm{l} 0.5 \mathrm{~N}$ sodium hydroxide in $80 \%$ ethanol and unmetabolised benzo(a)pyrene was extracted by hexane and counted in a scintillation counter. The linearity of the assay has been checked in rat intestine. ${ }^{16}$ Aryl hydrocarbon hydroxylase activities were expressed as $\mathrm{pmol} / \mathrm{min} / \mathrm{mg}$ protein.

The epoxide hydrolase activity was measured with a modification of the method of Oesch ${ }^{17}$ using radioactive 4,5-benzpyrene oxide as a substrate: 25 $\mu \mathrm{l}$ intestinal homogenate, $25 \mu \mathrm{l}$ buffer, and $2 \mu \mathrm{l} 4,5$ benzpyrene oxide were incubated for 20 minutes. The reaction was stopped with $50 \mu \mathrm{l} 20 \mathrm{nM} \mathrm{CdSO}{ }_{4}$ and $100 \mu \mathrm{l}$ DMSO and extracted with $1 \mathrm{ml}$ ether four times. The remaining activity was counted in a scintillation counter after adding of $0.8 \mathrm{ml}$ water. The linearity and saturation kinetics of the method are published elsewhere by Hietanen et al. ${ }^{18}$ The results were expressed as $\mathrm{pmol} / \mathrm{min} / \mathrm{mg}$ protein.

The glutathione peroxidase activity was measured according to a modification of the kinetic method of Paglia and Valentine ${ }^{19}$ the linearity of the reaction is controlled during the course of the assay. After incubating glutathione, NADPH, glutathione reductase, and $50 \mu \mathrm{l}$ intestinal homogenate, $100 \mu \mathrm{l}$ cumene hydroperoxide was added as the enzyme substrate and the consumption of $\mathrm{NADPH}^{+}$was 
recorded at $37^{\circ} \mathrm{C}$ on the wave length of $340 \mathrm{~nm}$. The results were expressed as $\mathrm{nmol} / \mathrm{min} / \mathrm{mg}$ protein.

All the assays used in this work are long established routines in our laboratory. The storage of the samples at $-70-80^{\circ} \mathrm{C}$ does not significantly affect the enzyme activities. ${ }^{1020}$ The coefficients of variation of the methods have been published recently. ${ }^{21}$

\section{STATISTICAL METHODS}

Standard descriptive statistics, correlations of two variables, Student's $t$ test, and analysis of variance were used.

\section{Results}

Normal histology was found in 201 small intestinal biopsies. The mean age of these children was $6 \cdot 3$ (SD 5.1) years. Pathological villous structure was found in 41 biopsy specimens: the mean age of the 21 children with partial villous atrophy was $6 \cdot 2$ (SD 5.7) years, and the mean age of the 20 children with severe villous atrophy was $8.6(\mathrm{SD} 5 \cdot 7)$ years.

\section{NORMAL MUCOSA}

Among the 201 children with normal biopsy there were 142 children who did not have any chronic disease: their symptoms were constitutional, functional, or transitory. We consider these children as healthy. The normal development of mucosal biotransformation rates by age was studied in these children. The alkaline phosphatase activity was constant throughout childhood. The aryl hydrocarbon hydroxylase, epoxide hydrolase, and glutathione peroxidase activities were detectable in all age groups. The aryl hydrocarbon hydroxylase activity increased by age; the correlation coefficient was $0.308 \quad(\mathrm{p}<0.001)$. The epoxide hydrolase and glutathione peroxidase activities were unaffected by age (Table 1). There were no significant differences by sex in any of the studied enzymes. There were no significant correlations between the biotransformation enzymes and the alkaline phosphatase activities: the correlation coefficient between alkaline phosphatase and aryl hydrocarbon hydroxylase was 0.023 , between alkaline phosphatase and epoxide hydrolase $0 \cdot 041$, and between alkaline phosphatase and glutathione peroxidase (0.070 suggesting that the alkaline phosphatase activity used as a reference enzyme reflecting mucosal state was independent from the other studied enzymes.

Among the children with normal mucosa there were 26 children with insulin dependent diabetes mellitus and 21 children with juvenile rheumatoid arthritis. There were no differences in the activities of alkaline phosphatase, aryl hydrocarbon hydroxylase, epoxide hydrolase, or glutathione peroxidase between these disease groups and age matched healthy children (data not shown).

\section{PATHOLOGICAL MUCOSA}

The biopsy specimens with abnormal villi tended to be lighter than the normal samples. The alkaline phosphatase activities were significantly reduced in villous atrophy: the activity in the samples with partial villous atrophy was $73 \%(\mathrm{p}<0.01)$ and in the samples with severe villous atrophy $34 \%(p<0 \cdot 001)$ of the activity in normal samples.

Partial villous atrophy did not differ significantly from normal mucosa regarding aryl hydrocarbon hydroxylase, epoxide hydrolase, or glutathione peroxidase activities. In severe villous atrophy, aryl hydrocarbon hydroxylase activity was normal but the activities of epoxide hydrolase and glutathione peroxidase were diminished as compared to normal biopsies, $\mathrm{p}<0 \cdot(05$ and $\mathrm{p}<0 \cdot() 2$, respectively (Table 2 ).

According to the analyses of variance, the activities of alkaline phosphatase, epoxide hydrolase, and glutathione peroxidase varied significantly in relation to histology; the F-values were $31 \cdot 675,3 \cdot 183$, and 3.093 respectively. The differences in aryl hydro-

Table 1 Activities* of alkaline phosphatase $(A P)$, aryl hydrocarbon hydroxylase $(A H H)$, epoxide hydrolase $(E H)$, and glutathione peroxidase (GSHPx) in jejunal biopsies in relation to age among healthy children

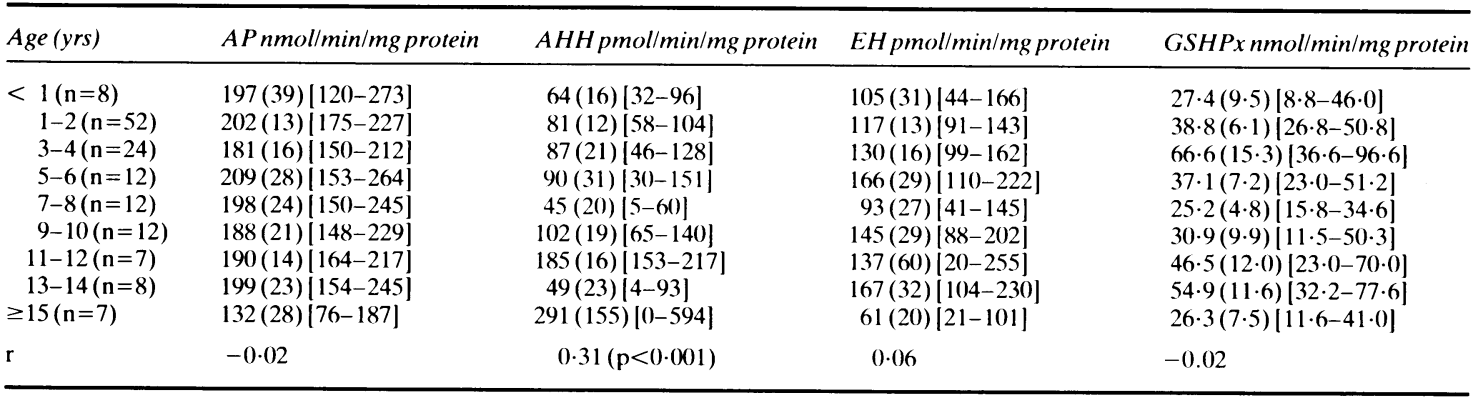

${ }^{*}$ mean (SE) 95\% confidence limits within square brackets. 
Table 2 Activities* of alkaline phosphatase $(A P)$, aryl hydrocarbon hydroxylase $(A H H)$, epoxide hydrolase $(E H)$, and glutathione peroxidase (GSHPx) in jejunal biopsies in relation to histological findings

\begin{tabular}{|c|c|c|c|}
\hline & Normal villi & $\begin{array}{l}\text { Partial villous } \\
\text { atrophy }\end{array}$ & $\begin{array}{l}\text { Severe villous } \\
\text { atrophy }\end{array}$ \\
\hline $\mathrm{n}$ & 201 & 21 & 20 \\
\hline Age, yrs & $\begin{array}{r}6 \cdot 3(0 \cdot 4) \\
{[5 \cdot 5-7 \cdot 1]}\end{array}$ & $\begin{array}{r}6 \cdot 2(1 \cdot 2) \\
{[3 \cdot 8-8 \cdot 6]}\end{array}$ & $\begin{array}{c}8 \cdot 6(1 \cdot 3) \\
{[6 \cdot 1-11 \cdot 1]}\end{array}$ \\
\hline Weight, mg & $\begin{array}{r}6 \cdot 10(0 \cdot 32) \\
{[5 \cdot 47-6 \cdot 73]}\end{array}$ & $\begin{array}{r}4 \cdot 69(0 \cdot 76) \\
{[3 \cdot 20-6 \cdot 18]}\end{array}$ & $\begin{array}{l}3 \cdot 26(1 \cdot 96) \\
{[0-7 \cdot 10]}\end{array}$ \\
\hline $\begin{array}{l}\mathrm{AP}, \llbracket \mathrm{nmol} / \mathrm{min} / \\
\mathrm{mg} \text { protein }\end{array}$ & $\begin{array}{l}210(6) \\
{[199-221]}\end{array}$ & $\begin{array}{c}153(16) \dagger \\
{[121-185]}\end{array}$ & $\begin{array}{l}72(5) \ddagger \\
{[62-81]}\end{array}$ \\
\hline $\begin{array}{l}\mathrm{AHH} \text {, } \neq \neq \mathrm{pmol} / \mathrm{min} / \\
\text { mg protein. }\end{array}$ & $\begin{array}{l}102(10) \\
{[82-123]}\end{array}$ & $\begin{array}{c}139(71) \\
{[0-279]}\end{array}$ & $\begin{array}{c}97(23) \\
{[51-142]}\end{array}$ \\
\hline $\begin{array}{l}\mathrm{EH},{ }^{* *} \mathrm{pmol} / \mathrm{min} / \\
\mathrm{mg} \text { protein }\end{array}$ & $\begin{array}{c}128(7) \\
{[114-141]}\end{array}$ & $\begin{array}{l}94(17) \\
{[62-127]}\end{array}$ & $\begin{array}{r}79(15) \S \\
{[50-108]}\end{array}$ \\
\hline $\begin{array}{l}\text { GSHPx, }+\dagger \text { nmol/ } \\
\mathrm{min} / \mathrm{mg} \text { protein }\end{array}$ & $\begin{array}{c}41 \cdot 5(2 \cdot 1) \\
{[37 \cdot 4-45 \cdot 6]}\end{array}$ & $\begin{array}{r}45 \cdot 4(11 \cdot 0) \\
{[23 \cdot 8-67 \cdot 0]}\end{array}$ & $\begin{array}{l}16 \cdot 3(3 \cdot 8) \| \\
{[8 \cdot 9-23 \cdot 7]}\end{array}$ \\
\hline
\end{tabular}

${ }^{*}$ mean (SE) $95 \%$ confidence limits within square brackets; Student's $t$ test, significances of the differences from normal mucosa: $\dagger p<0 \cdot 01$, $\ddagger \mathrm{p}<0.001, \S \mathrm{p}<0.05, \| \mathrm{p}<0.02$; Analysis of variance: $\mathbb{\| p}<0.001(\mathrm{~F}$ $31 \cdot 675),{ }^{* *} \mathrm{p}<0.05(\mathrm{~F} 3 \cdot 183),+\dagger \mathrm{p}<0.05(\mathrm{~F} 3 \cdot 093), \ddagger \neq p>0 \cdot 05(\mathrm{~F}$ $0 \cdot 431)$.

carbon hydroxylase activities were insignificant also in analysis of variance, $\mathrm{F} 0.431$.

\section{Discussion}

It is known from animal studies and adult human studies that the gastrointestinal mucosa has several biotransformation enzyme activities including both phase I reactions of functionalisation and phase II reactions of conjugation in the metabolism of xenobiotics and endogenous substances such as steroid hormones, bile acids, and prostaglandins. ${ }^{622}$

Polycyclic hydrocarbons are a large group of chemical compounds which are abundant in the environment in industralised countries. General population is also exposed to polycyclic hydrocarbons through consuming broiled and smoked food as well as through certain drugs and environmental pollution. Polycyclic hydrocarbons are potentially carcinogenic as they are biotransformed to epoxides which bind covalently to intracellular macromolecules. Coke oven workers who were exposed to polycyclic hydrocarbons including benzo(a)pyrene were shown recently to have benzo(a)pyrene diol epoxide-DNA adducts in peripheral lymphocytes and antibodies against the adducts in serum as indications of the metabolism of benzo(a)pyrene in vivo. ${ }^{2324}$

In unexposed laboratory animals, the levels of biotransformation enzymes are low after birth and increase gradually postnatally ${ }^{3}$ but when enzyme inducers are administered into pregnant or lactating females, the aryl hydrocarbon hydroxylase ${ }^{25}{ }^{26}$ and epoxide hydrolase ${ }^{2728}$ activities increase significantly in weanling rats. The development of these enzymes in different human tissues during childhood has not so far been investigated. We found measurable concentrations of aryl hydrocarbon hydroxylase and epoxide hydrolase in jejunal biopsy samples in all age groups of children. This indicates that the induction of enzyme synthesis has taken place during pregnancy or very early childhood or that there exists a natural basal activity of aryl hydrocarbon hydroxylase and epoxide hydrolase in man. The intestinal mucosa of children has enzyme activities for the biotransformation of polycyclic hydrocarbon as well as for further metabolism of their oxygenated derivatives. Normal mucosa may also participate in the biotransformation of endogenous steroids and structurally related compounds.

Glutathione peroxidase is the main known site of selenium in human body and glutathione peroxidase has been found in most human tissues, " most often investigated in blood cells, plasma, and serum. ${ }^{24}$ Glutathione peroxidase protects tissues from oxidative damage by catalysing the reduction of hydrogen peroxide and organic hydroperoxides thus preventing the progression of tissue destruction initiated by these oxidated compounds. Glutathione peroxidase is thought to be a cytosolic alternative to peroxisomal activities." Our results show that glutathione peroxidase is present in the jejunal mucosa of normal children in constant quantities during the entire childhood.

We classified biopsy specimens in normal, partial villous atrophy, and severe villous atrophy by visual evaluation. The alkaline phosphatase activities proved that the visual evaluations of histology were correct as the alkaline phosphatase activity of crypts is shown to be about half of the activity of villous tips. ${ }^{31}$ The aryl hydrocarbon hydroxylase activity of mucosa with villous damage was similar to normal mucosa suggesting that oxygenated derivatives are formed at normal rates. The diminished concentrations of epoxide hydrolase and glutathione peroxidase in mucosal samples with severe villous atrophy indicate that the capacity of mucosa with villous damage to metabolise formed oxygenated derivatives is decreased.

Studies on the association between serum selenium concentrations and cancer arrive at controversial results. ${ }^{31-33}$ Maybe tissue contents of selenium and tissue activities of glutathione peroxidase are more important for the development of malignancy than serum levels. Coeliac disease has been associated with cancer, particularly with malignant gastrointestinal lymphomas, in case reports ${ }^{3+37}$ as well as in an extensive British multicentre study. ${ }^{38}$ Our results 
could provide an explanation for increased risk of cancer in patients with untreated or poorly treated coeliac disease: jejunal mucosa with severe villous atrophy may accumulate oxidated metabolites of xenobiotics as a consequence of intact aryl hydrocarbon hydroxylase activity but defective detoxication due to impaired epoxide hydrolase and glutathione peroxidase activities.

We thank Prof JK Visakorpi for histological consultations, Ms Leena Söderholm for technical assistance, and Ms Sanna Salanterä for computer analyses.

\section{References}

1 Hietanen E, Bartsch H, Ahotupa M, Park SS, Gelboin $\mathrm{HV}$. Tissue specificity of extrahepatic monooxygenases in the metabolism of xenobiotics. In: Siest G, ed. Drug metabolism. Molecular approaches and pharmacological implications. Oxford: Pergamon Press, 1985: 141-6.

2 Hänninen $\mathrm{O}$, Aitio $\mathrm{A}$, Hietanen E. Physiological defence against xenobiotics at their portals of entry to the organism. Med Biol 1979; 57: 251-5.

3 Chhabra RS. Intestinal absorption and metabolism of xenobiotics. Environ Hlth Perspect 1979; 33: 61-9.

4 Vainio H, Hietanen E. Role of extrahepatic metabolism. In: Jenner P, Testa B, eds. Concepts in drug metabolism. New York: Marcel Dekker, 1980; A: 251-83.

5 Hietanen E. Oxidation and subsequent glucuronidation of 3,4-benzopyrene in everted intestinal sacs in control and 3-methylcholantrene-pretreated rats. Pharmacology 1980; 21 : 233-43.

6 Laitinen M, Watkins III JB. Mucosal biotransformation. In: Rozman K, Hänninen O, eds. Gastrointestinal toxicology. Amsterdam: Elsevier, 1986: 169-92.

7 Poland A, Glover E. Comparison of 2,3,7,8tetrachlorodibenzo-p-dioxin, a potent inducer of aryl hydrocarbon hydroxylase, with 3-methylcholantrene. Mol Pharmacol 1973; 10: 349-59.

8 Uziel M, Griffin GD, Walsh PJ. Aryl hydrocarbon hydroxylase tissue-specific activities: evidence for baseline levels in mammalian tissues. $J$ Toxicol Environ Health 1985; 16: 727-42.

9 Wattenberg LW. Carcinogen-detoxifying mechanisms in the gastrointestinal tract. Gastroenterology 1966; 51: 932-5.

10 Clifton G, Kaplowitz N. The glutathione S-transferases of small intestine in the rat. Cancer Res 1977; 37: 788-91.

11 Prasad A. Selenium. In: Prasad A. Trace elements and iron in human metabolism. New York: Plenum Publishing Corporation, 1978: 215-40.

12 Hoensch HP, Steinhardt HJ, Weiss G, Haug G, Maier A, Malchow H. Effect of semisynthetic diets on xenobiotic metabolizing enzyme activity and morphology of small intestinal mucosa in humans. Gastroenterology 1984; 86: 1519-30.

13 Lowry $\mathrm{OH}$, Rosebrough NJ, Farr AL, Randall RJ. Protein measurement with folin phenol reagent. $J$ Biol Chem 1951; 193: 265-75.
14 Hietanen E. Regulation of enzyme levels in the small intestinal mucosa. University of Turku, Turku: Academic dissertation, 1973: 1-76.

15 DePierre JW, Moron MS, Johannesen KAM, Ernster L. A reliable and convenient radioactive assay for benzpyrene monooxygenase. Anal Biochem 1975; 63: 470-84.

16 Hietanen E, Laitinen $M$, Dependence of intestinal biotransformation on dietary cholesterol. Biochem Pharmacol 1978; 27: 1095-7.

17 Schassmann HU, Glatt HR, Oesch F. A rapid assay for epoxide hydratase activity with benxo(a)pyrene $4,5,-(\mathrm{K}$ region)oxide as substrate. Anal Biochem 1976; 74: 94-104.

18 Hietanen E, Malaveille C, Camus A-M, et al. Interstrain comparison of hepatic and renal microsomal carcinogen metabolism and liver S9-mediated mutagenicity in DA and Lewis rats phenotyped as poor and extensive metabolizers of debrisoquine. Drug Metab Disp 1986; 14: $118-26$.

19 Paglia DE, Valentine WN. Studies on the quantitative and qualitative characterisation of erythrocyte glutathione peroxidase. J Lab Clin Med 1967; 70: 158-69.

20 Tredger JM, Chhabra RS. Preservation of various microsomal drug metabolizing components in tissue preparations from the livers, lungs, and small intestines of rodents. Drug Metab Disp 1976; 4: 451-9.

21 Hietanen E, Ahotupa M, Béréziat J-C, Park SS, Gelboin HV, Bartsch H. Monoclonal antibody characterization of hepatic and extrahepatic cytochrome $\mathrm{P}-450$ activities in rats treated with phenobarbital or methylcholanthrene and fed various cholesterol diets. Biochem Pharmacol 1987; 36: 3973-80.

22 Hartiala K. Metabolism of hormones, drugs, and other substances by the gut. Physiol Rev 1973; 53: 496-534.

23 Harris CC, Vähäkangas K, Newman MJ, et al. Detection of benzo(a)pyrene diol epoxide-DNA adducts in peripheral blood lymphocytes and antibodies to the adducts in serum from coke oven workers. Proc Natl Acad Sci USA 1985; 82: 6672-6.

24 Haugen A, Becher G, Benestad C, et al. Determination of polycyclic aromatic hydrocarbons in the urine, benzo(a)pyrene diol epoxide-DNA adducts, and antibodies to the adducts in sera from coke oven workers exposed to measured amounts of polycyclic aromatic hydrocarbons in the work atmosphere. Cancer Res 1986; 46: 4178-83.

25 Alvares AP, Kappas A. Induction of aryl hydrocarbon hydroxylase by polychlorinated biphenyls in the foetoplacental unit and neonatal livers during lactation. FEBS Lett 1975; 50: 172-4.

26 McCormack KM, Melrose P, Rickert DE, Dent JG, Gibson JE, Hook JB. Concomitant dietary exposure to polychlorinated biphenyls and polybrominated biphenyls: tissue distribution and aryl hydrocarbon hydroxylase activity in lactating rats. Toxicol Appl Pharmacol 1979; 47: 95-104.

27 Dent JG, Cagen SZ, McCormack KM, Rickert DE, Gibson JE. Liver and mammary arylhydrocarbon hydroxylase and epoxide hydratase in lactating rats fed polybrominated biphenyls. Life Sci 1977; 20: 2075-80. 
28 Berry DL, Slaga TJ, Wilson NM, et al. Transplacental induction of mixed-function oxygenases in extra-hepatic tissues by 2,3,7,8-tetrachlorodibenzo- $p$-dioxin. Biochem Pharmacol 1977; 26: 1383-8.

29 Ward KP, Arthur JR, Russell G, Aggett PJ. Blood selenium content and glutathione peroxidase activity in children with cystic fibrosis, coeliac disease, asthma, and epilepsy. Eur J Pediatr 1984; 142: 21-4.

30 Dawson JR, Bridges JW. Intestinal microsomal drug metabolism, a comparison of rat and guinea-pig enzymes, and of rat crypt and villous tip cell enzymes. Biochem Pharmacol 1981; 30: 2425-30.

31 Salonen JT, Alfthan G, Huttunen JK, Puska P. Association between serum selenium and the risk of cancer. Am J Epidemiol 1984; 120: 342-9.

32 Willett WC, Polk BF, Morris JS, et al. Prediagnostic serum selenium and risk of cancer. Lancet 1983; ii: 130-4.

33 Robinson MF, Godfrey PJ, Thomson CD, Rea HM, van, Rij AM. Blood selenium and glutathione peroxidase activity in normal subjects and in surgical patients with and without cancer in New Zealand. Am J Clin Nutr 1979; 32: 1477-85.

34 Arnaud-Battandier F, Schmitz J, Ricour C, Rey J. Intestinal malignant lymphoma in a child with familial celiac disease. J Pediatr Gastroenterol Nutr 1983; 2: 320-3.

35 Verkasalo M, Savilahti E, Rapola J, Wallgren EI. Fibrosarcoma in a girl with celiac disease and IgA deficiency. J Pediatr Gastroenterol Nutr 1985; 4: 839-41.

36 Freeman HJ, Chiu BK. Multifocal small bowel lymphoma and latent celiac sprue. Gastroenterology 1986; 90: 1992-7.

37 Freeman HJ, Chiu BK. Small bowel malignant lymphoma complicating celiac sprue and the mesenteric lymph node cavitation syndrome. Gastroenterology 1986; 90: 2008-12.

38 Swinson CM, Slavin G, Coles EC, Booth CC. Coeliac disease and malignancy. Lancet 1983; i: 111-5. 